$\begin{array}{ll}\text { Abstracta Iranica } & \begin{array}{l}\text { Abstracta Iranica } \\ \text { Revue bibliographique pour le domaine irano-aryen }\end{array} \\ & \text { Volume } 22 \mid \mathbf{2 0 0 1} \\ & \text { Comptes rendus des publications de } 1999\end{array}$

\title{
Dictionnaire Français-Pashto. L'Asiathèque, Paris, 1999, 448 p.
}

\section{Nadjib Manalaï}

\section{OpenEdition}

1 Journals

\section{Édition électronique}

URL : http://journals.openedition.org/abstractairanica/36204

DOI : 10.4000/abstractairanica.36204

ISSN : 1961-960X

Éditeur :

CNRS (UMR 7528 Mondes iraniens et indiens), Éditions de l'IFRI

\section{Édition imprimée}

Date de publication : 15 mai 2001

ISSN : 0240-8910

\section{Référence électronique}

Nadjib Manalaï, "Dictionnaire Français-Pashto. L'Asiathèque, Paris, 1999, 448 p. », Abstracta Iranica [En ligne], Volume 22 | 2001, document 65, mis en ligne le 25 mars 2010, consulté le 11 octobre 2020

URL : http://journals.openedition.org/abstractairanica/36204 ; DOI : https://doi.org/10.4000/ abstractairanica.36204

Ce document a été généré automatiquement le 11 octobre 2020.

Tous droits réservés 


\section{Dictionnaire Français-Pashto. L'Asiathèque, Paris, 1999, 448 p.}

\section{Nadjib Manalaï}

Avec un corpus de quelque 13000 mots, l'ouvrage constitue un précieux outil pour l'étude du pachto. Chaque mot est donné avec sa transcription et sa traduction. Les différents sens des mots sont rendus avec une grande précision. Des repères typographiques permettent de préciser le degré de synonymie des traductions.

2 Dans une introduction d'une trentaine de pages Daniel Septfonds présente de manière succincte et précise des aspects fondamentaux de la grammaire du pachto.

\section{INDEX}

Thèmes : 2.2. Langues vivantes et dialectes

\section{AUTEURS}

NADJIB MANALAÏ

INaLCO - Paris 